\title{
A mezőgazdasági biztosítási piac újszerü megoldásainak vizsgálata a marketing és környezetvédelem tükrében
}

Szakács, Attila - Szakács, Zsolt:

Agricultural Insurance Market a New Solution of Marketing and Environment Protection

The agricultural mitigation fund operating deficit expanded in 2012 to a price support for agricultural insurance business helped construct. (Figure 1). The legislation aims to provide a wide range of farmers' risk community to organize and strengthen the affected self-care responsibility. The new extended two-level agricultural risk management system in 2012 and 2013 were not used in the full amount. Further dissemination of this 2014 novel possibility of a major issue in the insurance market. We have to examine how market participants are informed and how to better disseminate of marketing solutions?

Keywords: financial point of view, agriculture, insurance, innovative marketing solutions

\section{ÖSSZEFOGLALó}

A hiányosan müködő mezőgazdasági kárenyhítési alap kiegészült 2012-től egy dijtámogatással segített üzleti mezőgazdasági biztosítási konstrukcióval. (1. ábra). A törvényi szabályozás célkitűzése, hogy a mezőgazdasági termelők széles körét kockázatközösségbe szervezze, valamint erősítse az érintettek öngondoskodási felelősségvállalását. Az új, kibővített, kétszintű mezőgazdasági kockázatkezelő rendszerből 2012-ben és 2013-ban sem került felhasználásra a teljes összeg. 2014-re ezen újszerű lehetőség további elterjesztése egy fontos kérdése a biztosítási piacnak. Feladatunk, hogy megvizsgáljuk a piaci szereplők mennyire tájékozottak illetve, hogy milyen marketing megoldásokkal lehet jobban elterjeszteni és "csábítóbbá" tenni?

Kulcsszavak: pénzügyi nézőpont, mezőgazdaság, biztosítás, újszerű marketing megoldások

\section{CÉLKITŰZÉSEINK}

A Szolnoki Főiskola és a SZIE munkatársai 2011 óta folytatnak kutatásokat a vállalkozások és kiemelten a mezőgazdasági vállalkozások felelős- ségi és biztosítási témakörében. $A$ termékek és szolgáltatások megméretésére a piacon kerül sor, az ott uralkodó szigorú versenyfeltételek között. A közös kutatásunkban a következő lépése volt a piaci szereplők véleményének és ismereteinek - újszerű megoldások iránti nyitottságának - feltérképezése mély interjús technika segítségével.

\section{A KUTATÁs MENETE}

A Keleti régiókra vonatkozóan mélyinterjúk (30) segítségével mértünk fel három jól elkülönített társadalmi szférát. A társadalmon belül: magán szféra, közigazgatási szervezetek és gazdálkodó szervezetek vizsgálatát hajtottuk végre. Ezek a csoportok alapvetően különböznek biztosítási és környezetvédelmi ismereteiket és kompetenciájukat illetően. A megkérdezetteket igyekeztünk úgy kiválasztani, hogy reprezentativ mintához jussunk és így valós képet kapjunk a vizsgált régiók, biztosítási és környezetvédelmi fejlettségéről és hiányosságairól. Az említett szférák valós arányaihoz és a mezőgazdasági biztosítások területén betöltött szerepük sú- 


\section{1. ábra: A társadalmi szférák megoszlása}

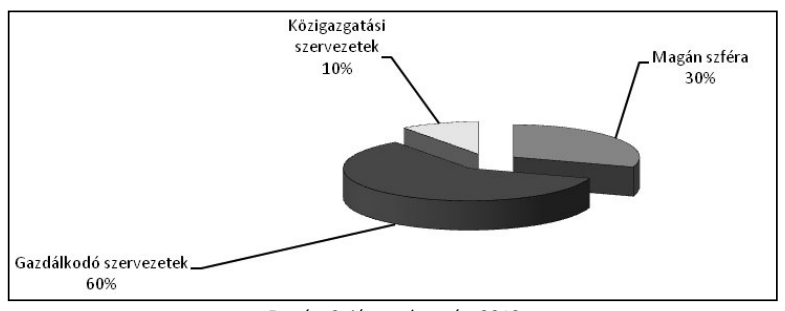

Forrás: Saját szerkesztés, 2013

díjához nyújtott támogatás igénybevételi feltételeiről. A rendszerben tehát az állam is részt vesz és az eddigieknél hatékonyabb segítséget kíván nyújtani az elháríthatatlan külső ok (vis maior) miatti káresemények negatív hatásainak enyhítésében." (1)

Feladatunknak éreztük, hogy áttekintést nyújtsunk mind az

lyához igazítottuk 60\%-ban gazdálkodó szervezetet, 10\%-ban közigazgatási szervezetet és 30\%-ban magán személyt választottunk ki (3.ábra) véletlenszerűen a régiókból és kérdeztünk meg mélyinterjú keretein belül. A megkérdezett három csoporthoz hasonló kérdéscsoportokat készítettünk, mely kérdések azonos csoporton belül jellemzően ismétlődtek. Kisebb eltérések természetesen adódtak a megkérdezett személyek és szervezetek sajátosságaiból adódóan, azonban ez nem vezet összevetési vagy összehasonlíthatósági nehézségekhez. Az összegzést csoportok szerint bontjuk, a jellemző kérdéseket a rájuk adott általánosítható válaszokkal, megjegyzésekkel és következtetésekkel közöljük. Terjedőben vannak a „farmtól az asztalig" elven szerveződő termelő-feldolgozó-értékesítő láncok is. " (1)

\section{AZ ÚJSZERŨ MEZŐGAZDASÁGI BIZTOSÍTÁs ÜZLETI LEHETŐSÉGE AKÁR 65\%-OS DÍJTÁMOGATÁSSAL.}

„A mezőgazdasági kockázatkezelő rendszer feltételeit két jogszabály írja le. Az egyik jogszabály a 2011. évi CLXVIII. törvény a mezőgazdasági termelést érintő időjárási és más természeti kockázatok kezeléséről, a másik pedig a hozzá kapcsolódó 143/2011. (XII. 23.) VM rendelet a mezőgazdasági biztosítás (növénybiztosítás)

első pillérről, azaz a mezőgazdasági kárenyhítési alap működéséről, mind pedig a kockázatkezelő rendszer második pillérjéről a díjtámogatott mezőgazdasági növénybiztosítások típusairól. 2012-től elindult új, kibővített, kétszintű me-

\section{2. ábra: A mezőgazdasági biztositás újszerü üzleti folyamata}

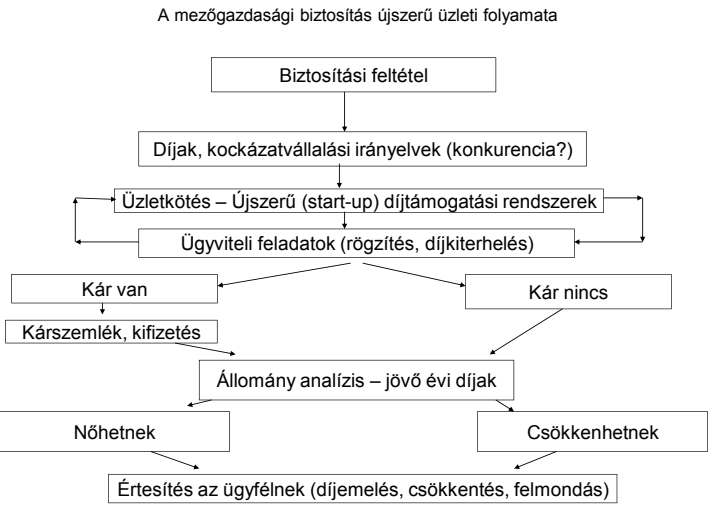

Forrás: Saját szerkesztés, 2013

zőgazdasági kockázatkezelő rendszerből 2012 ben és 2013-ban sem került felhasználásra a teljes összeg. 2014-re ezen újszerű lehetőség további elterjesztése egy fontos kérdése a biztosítási piacnak.

Milyen marketing megoldásokkal lehetne jobban elterjeszteni és "csábítóbbá" tenni? Első sorban meg kell ismertetni a gazdákkal ezen megoldásokat és meg kell ragadni erre minden lehetőséget. Az eddig is meglévő és működő mezőgazdasági kárenyhítési alap kiegészült egy 
dijtámogatással segített üzleti mezőgazdasági biztosítási konstrukcióval.(2. ábra)

„A mezőgazdasági kockázatkezelő rendszer feltételeit két jogszabály írja le. Az egyik jogszabály a 2011. évi CLXVIII. törvény a mezőgazdasági termelést érintő időjárási és más természeti kockázatok kezeléséről, a másik pedig a hozzá kapcsolódó 143/2011. (XII. 23.) VM rendelet a mezőgazdasági biztosítás (növénybiztosítás) dijához nyújtott támogatás igénybevételi feltételeiről. A törvényi szabályozás célja, hogy a mezőgazdasági termelők széles körét kockázatközösségbe szervezze, valamint erősítse az érintettek öngondoskodási felelősségvállalását. A rendszerben tehát az állam is részt vesz és az eddigieknél hatékonyabb segítséget kíván nyújtani az elháríthatatlan külső ok (vis maior) miatti káresemények negatív hatásainak enyhítésében." (1) Feladatunknak érezzük, hogy áttekintést nyújtsunk mind az első pillérről, azaz a mezőgazdasági kárenyhítési alap működéséről, mind pedig a kockázatkezelő rendszer második pillérjéről a díjtámogatott mezőgazdasági növénybiztosítások típusairól.

A kockázatkezelő rendszer első pillérjében való részvétel múködhet önkéntes és kötelező alapon is. Kötelező a rendszerben való részvétel azoknak a mezőgazdasági termelőknek, akik legalább10 hektáron termelnek szántóföldi kultúrákat, vagy legalább 5 hektáron termelnek szántóföldi zöldséget, vagy legalább 1 hektáron folytatnak ültetvényművelést. Ugyancsak kötelező a részvétel azoknak a mezőgazdasági termelőknek, akik legalább 5 hektárnyi területen folytatnak zöldségtermesztést és ültetvényművelést. A felsorolt kategóriákba nem tartozó termelők önkéntesen csatlakozhatnak a kárenyhítő rendszerhez. Az önkéntes csatlakozás esetén azonban minimálisan három éves időtartamra kell csatlakozni. A kockázatközösség tagjaivá váló termelők évente kötelesek ún. kárenyhítési hozzájárulást fizetni és egyúttal jogosultak a kárenyhítési alapból ún. kárenyhítési juttatást igénybe venni.
Adódik a kérdés, hogy mennyit kell befizetni a termelőnek? Ültetvények és szántóföldi zöldség termesztési terület után hektáronként és évente $3000 \mathrm{Ft}$, más szántóföldi kultúrák után pedig hektáronként és évente $1000 \mathrm{Ft} \mathrm{a}$ kötelezően befizetendő összeg. Ezeket az öszszegeket évente szeptember 15.-ig kell átutalni a kárenyhítési alap számlájára. $\mathrm{A}$ kárenyhítési alapból a termelők akkor kaphatnak kárenyhítő juttatást, ha őket igazolt jégesőkár, belvízkár, viharkár, tavaszi fagykár, téli fagykár, felhőszakadáskár, valamint mezőgazdasági árvízkár, vagy aszálykár érte és ezen káreseményeket az ún. agrárkár- megállapító szerv is megállapítja. A megállapítás érdekében az elszenvedett káreseményeket 15 napon belül kell bejelenteni. Az agrárkár-megállapító szervezet a bejelentett kárról, annak helyéről és mértékéről, valamint a hozamérték csökkenés mértékéről hatósági bizonyítványt állít ki. A bizonyítvány kiállítás illetékmentes és azt csatolni kell a kárenyhítő juttatás iránti kérelemhez. A kárenyhítő juttatás iránti kérelmet legkésőbb a tárgyév november végéig kell benyújtania az agrárkár-megállapító szervhez, amely szervnek a tárgyévet követő január 15.-ig kell azt továbbítania a a mezőgazdasági igazgatási szervhez. A kárenyhítő juttatások kifizetése pedig a tárgyévet követő március 31.-e után kezdődik. A kárenyhítő juttatás mértékének alapja a tárgyévet megelőző három elemikár-mentes év adatainak átlagához viszonyított hozamcsökkenés értékének $80 \%$-a.

A kockázatkezelő rendszer első pillérje ösztönzi a termelők öngondoskodását, mivel a kockázatközösségben tag mezőgazdasági termelő a neki járó kárenyhítő juttatásnak csak a felére jogosult, amennyiben nem köt a mezögazdasági káresemények közül az adott növényi kultúrára jellemző káreseményre kiterjedő hatályú mezőgazdasági biztosítást.

A kétszintű mezőgazdasági kockázatkezelő rendszer második pillérjében a mezőgazdasági termelők az időjárási kockázatokra kötött me- 
zőgazdasági növénybiztosítások dijához kaphatnak támogatást. $\mathrm{A}$ támogatás mértéke legfeljebb a nettó biztosítási dij 65\%-ig terjedhet. A támogatás mértéke 2012-ben összesen maximum 9,33 millió euró, azaz mintegy 2,7-2,9 milliárd forint lehet. Ha ezen összegnél több támogatási igény érkezik be a termelőktől, akkor a támogatás mértékét arányosan csökkentik.

A törvény, illetve a rendelet három típusú mezőgazdasági biztosítást nevesít: „A", „B" és „C $C$ " típusút. $A z$ „A" típusú mezőgazdasági növénybiztosítás hét időjárási kockázati tényezőt magába foglaló csomagbiztosítás, amely a legnagyobb mennyiségben és területen termesztett 11 jelentős növényre terjed ki. A biztosítási védelem a következő hét kártípusra terjed ki: jégesőkár, aszálykár, elemi kár okozta mezőgazdasági árvízkár, téli fagykár, tavaszi fagykár, fel-
A 38 növényfajta a következő: csemegeszőlő, zab, szója, lencse, borsó, lóbab, csemegekukorica, cukorrépa, zöldborsó, zöldbab, uborka, sárgadinnye, görögdinnye, paprika, füszerpaprika, paradicsom, káposzta, kelkáposzta, karfiol, brokkoli, sárgarépa, sütőtök, spárga, mák, szárazbab, burgonya, vöröshagyma, őszibarack, kajszi, körte, szilva, meggy, cseresznye, málna, ribizli, köszméte, szamóca és dió.

$A$ "C $C$ típusú mezőgazdasági növénybiztosítás keretében pedig az eddigiekben nem felsorolt növényfajták biztosithatók a következő kárnemekre: jégesőkár, aszálykár, árvízkár, téli fagykár, tavaszi fagykár, felhőszakadás kár, viharkár és tüzkár.

A felsorolt, díjtámogatásra jogosító biztosítási csomagokra egységesen az a jellemző, hogy 30\%-os ún. eléréses önrészt tartalmaznak, azaz

1. táblázat: Az EU -27 fontosabb mezőgazdasági adatai 2010

\begin{tabular}{|c|c|c|c|c|}
\hline Megnevezés & $\begin{array}{c}\text { Az ágazat hozzajárulása } \\
\text { a bruttó } \\
\text { hozzáadott értékhez, \% }\end{array}$ & $\begin{array}{c}\text { A mezõgazdasági } \\
\text { terület aránya } \\
\text { az ōsszes fốdterületból, } \%\end{array}$ & $\begin{array}{l}\text { Száz lakosra jutó mezó- } \\
\text { gazdasági terület, hektár }\end{array}$ & $\begin{array}{c}\text { Az ágazatban } \\
\text { foglalkoztatottak aránya, } \%\end{array}$ \\
\hline EU-15 országai & 1,5 & 41,9 & 34,2 & 2,8 \\
\hline Ebböl: Franciaország & 1,7 & 53,3 & 46,5 & 2,9 \\
\hline Késốbb csatlakozott országok & 3,7 & 48,4 & 51,0 & 11,9 \\
\hline Ebból: Magyarország & 3,8 & 62,2 & 57,8 & 4,4 \\
\hline Románia & 6,7 & 56,7 & 63,1 & 26,9 \\
\hline EU-27 országai & 1,7 & 43,5 & 37,7 & 4,7 \\
\hline
\end{tabular}

hőszakadás kár, viharkár és tűzkár. $A z$ „A” típusú növénybiztosításban a következő 11 féle növény biztositható: őszi búza, tavaszi búza, őszi árpa, tavaszi árpa, őszi káposztarepce, triticale, rozs, ipari napraforgó, takarmánykukorica, borszőlő és alma.

$A$ „ $B$ ” típusú mezőgazdasági növénybiztosítás keretében 38 növény termesztése esetén lehet szúkebb kockázati körben jégeső, téli fagykár, viharkár és tüzkár kockázatára biztosítást kötni. Ennél a biztosítási konstrukciónál a viharkárba beletartozik a homokverés által okozott kár is. amennyiben a károsodott területeken megállapított kárszázalék nem éri el a 30\%-ot, akkor a kár nem kerül térítésre.

Természetesen annak a termelőnek, aki soknak tartja ezt az önrészesedést, annak kínálnak a biztosítók olyan kiegészítő növénybiztosítást, amellyel a kárból viselt önrészesedés csak $5 \%$ lesz. Tudni kell, hogy az ilyen kiegészítő biztosítás dijja nem jogosult támogatásra.

A „2010. évi adatok szerint a mezőgazdaság bruttó hozzáadott értékhez való 3,8\%-os hozzájárulásának aránya az EU-27 országai között a 4. 
legmagasabb, a mezőgazdaságban foglalkoztatottak 4,4\%-os hányadával a magyar mezőgazdaság viszont csak a tizedik".(2) (1. táblázat)

Nézzük meg a Jász-Nagykun-Szolnok megyei szolgáltatásokkal foglalkozó nagyvállalatok megoszlását a 3. ábrán. Látható, hogy az országos átlagnál egy kicsit jobb a Mezőgazdaság aránya. Eddigi (2012) vizsgálatok keretében a vizsgált vállalkozások jelenlegi (current) és optimálisnak vélt, kívánatos (wish) marketingtevékenységi körének ismertetése és összehasonlítása történt meg. Az empirikus kutatási eredményeink feldolgozása jelen témában folyamatban van.

A szolgáltatások növekedésének okai:

- az életmód megváltozása,

- a gyors technológiai fejlődés,

- általános fejlődési tendenciák.

\section{3. ábra: A szolgáltatások szerepe a gazdaságban}

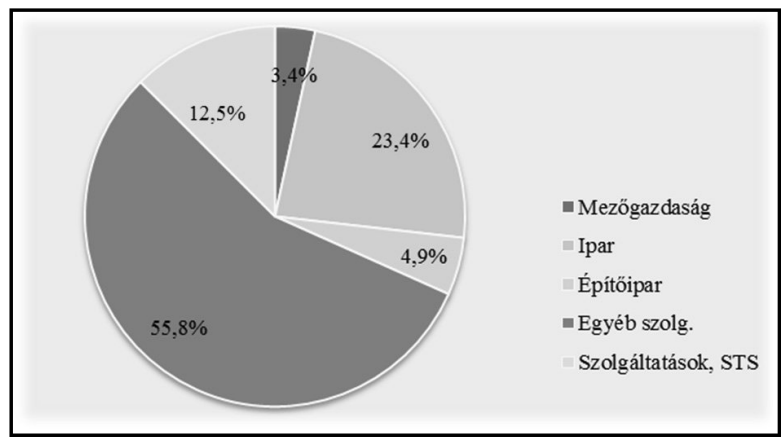

Forrás: A JNSZ- Megyei Szolgáltató Cégek Marketing Tevékenységének Vizsgálata, 2012 Máté Z - László É. - Szakács A

\section{A KELETI RÉGIÓBAN VÉGZETT MÉLYINTERJÚS KUTATÁS KÉRDÉSKÖREI ÉS ÖSSZEGZŐ EREDMÉNYEI}

\section{Magán szféra}

A három megkérdezett civil személyt véletlenszerűen választottuk ki. Törekedtünk arra, hogy családi állapot, nem, kor, képzett- ség szerint lehetőleg különbözzenek egymástól. A civil szférát talán generációk alapján lehet leginkább szétválasztani a vizsgálat szempontjából. A fiatalabb generáció, akik már az iskolában, ill. a családban is találkoznak, találkoztak és foglalkoztak biztosításokkal, ill. a környezetvédelemmel annak kezelésével és hatékony alkalmazásával, természetesen sokkal magától értetődőbb ennek jelentősége és mindennapisága. Az említett generáció nagyon sokat segíthet ezeknek az ismereteknek az idősebb generációk felé való közvetítésében és adaptálásában. Ez jó néhány esetben tetten érhető volt abban, hogy pl. a GFB biztosítások interneten való megkötésében sokan segítettek a szülőknek, ill. nagyszülőknek. A fizetési feltételek alakulása (4 ábra) ide vezethető vissza. A magán szférán belül nagyon nagy jelentőséggel bír a döntések meghozatalánál a személyek anyagi háttere, egy jól felszerelt lakás vagy nagy mezőgazdasági területek. A fejlődéssel, ill. az ehhez kapcsolódó ismeretek nagyon fontosak mivel ezek a vagyon értékek növekedése a technikai eszközök esetében pl. az informatika világában akár hetek alatt is bekövetkezhetnek. Ezzel állandóan lépést tartani és eszerint frissíteni az információkat nagy költséggel jár, szinte lehetetlen, de természetesen nem is ez a cél. Szerencsésnek mondhatják magukat azok a háztartások, amelyek megtalálták az egyensúlyt a kialakult kényszerpálya illetve saját korlátaik között. A megkérdezés az interjúalanyok személyiségi jogainak tiszteletben tartásával, anonimitásukat megőrizve zajlott le. 
4.ábra: Milyen gyakorisággal és módon szokott Ön a szolgáltatásokért fizetni

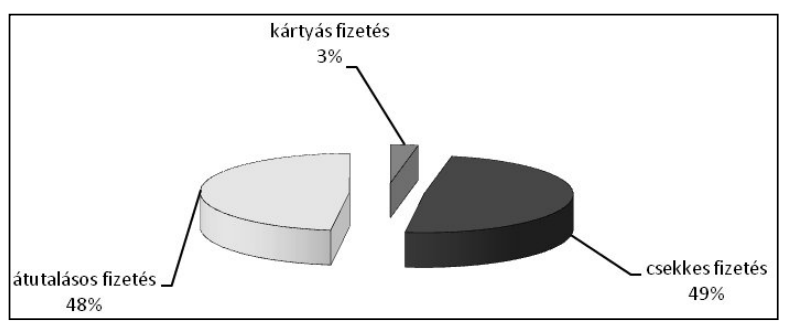

Forrás: Saját szerkesztés, 2013

\section{Közigazgatási szervezetek}

Többek között néhány felsőoktatási intézetet is - Egyetemet, Főiskolát - felkerestünk a kutatással kapcsolatban. Az egyetem kezelésében lévő mezőgazdasági területek és vagyontárgyak biztosításai nagyon érdekes problémára hívta fel figyelmünket.

A különböző mezőgazdasági szabályozók törvényalkotásakor nem minden esetben foglalkoznak e speciális terület kérdéseivel. Nehéz gazdasági helyzet őket is érintette és a jövő mezőgazdászait képző szervezetek támogatásaival újszerű - start-up - cégvezetői, ill. cégalapítási megoldásokkal próbálnak választ adni jelen szervezetek. Ugyan akkor elmondható, hogy a kérdésekre adott válaszok egyik részében kisebb, míg a gazdasági sajátosságok miatt nagyobb intervallumon belül ingadoznak a különbségek az egyes szervezetek között. Természetesen figyelembe vettük azt is, hogy a néhány szervezet jóval nagyobb súllyal rendelkezik a központi támogatási források allokálásakor.

A szervezetek főleg pályázati úton juthatnak hozzá a támogatáshoz, ami egy egészséges versengéshez vezet közigazgatási szférán belül. Természetesen érezhető különbség van a kicsi és a nagy szervezetek között pályázati források elnyerése alapján. Egy egyetem változatosabb lehetőségeket és körülményeket biztosít az innovációra bármilyen téren, mint egy vidéki kis főiskola. A térségi társulások rendszerének kialakítása - kormányzati támogatással - ezeket a különbségeket célozza halványítani.

A megkérdezettek túlnyomó többsége (5.ábra) nem használ hitelkártyát vagy bankkártyát fizetéskor $1 \%$. A pályázatírás adta lehetőségek kihasználása minden szervezet előtt nyitott, ezért nagy előnyt jelent, ha a szervezetek rendelkeznek pályázatírással foglalkozó, abban jártas és tapasztalt munkaerővel. Már évekkel ezelött megkezdődött a pályázatírás felértékelődése, mára szinte alapelvárás, hogy valamilyen szinten értsenek hozzá az alkalmazottak. Különböző pályázatíró tanfolyamok rendezésével javitható a munkavállalók versenyképessége és kompetenciája. 5.ábra: Milyen gyakorisággal és módon szokott Ön a szolgáltatásokért fizetni

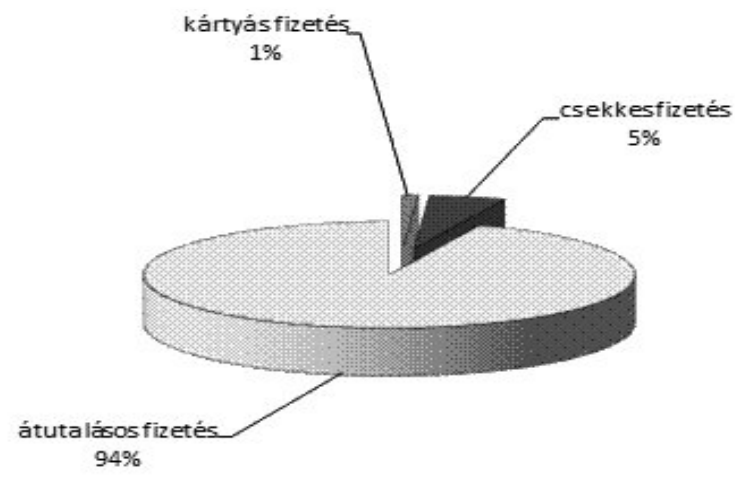

Forrás:Saját szerkesztés, 2013 


\section{Gazdálkodó szervezetek}

Alapvető piacgazdasági érdek, hogy minél szélesebb kockázati körben védelembe kerüljön a mezőgazdaságból élők. Amikor a mezőgazdasági biztosítások jövőjéről beszélünk akkor a mezőgazdaságból élőknél szélesebb társadalmi skálát kell figyelembe vennünk. Ilyen például a feldolgozóipar, szolgáltatók, bankok, biztosítók, kutatók, stb.... Amennyiben ezek közül az egyik tönkremegy, akkor annak minden pénzügyi kockázatát a többi szereplő is viseli. A fenntartható gazdálkodási egyensúly tehát nem feltétlen a nagy és hatékony, egy-egy kézben összpontosuló birtokok jelentik, mert hiszen lehet, hogy éppen ezek a kockázatok hordozói, mint pl. a mamut méretű állattenyésztési telepek, amelyek éppen a környezetszennyezés vagy járványok tekintetében jelenthetnek még jó ideig veszélyeket.

A megkérdezett gazdálkodó szervezetek közül 6 céggel közvetlenül is foglalkoztunk. Megkértük őket, hogy beszéljen kicsit részletesebben nekünk a különböző biztosításokkal kapcsolódó felkészültségükről és a környezetvédelemhez valamint a start-up megoldásokhoz fúződő viszonyukról. A cégeket úgy próbáltuk kiválasztani, hogy a legszélesebb körét képviselje a régiót jellemző szervezeteknek. Ebből kifolyólag széles skálán mozognak a kapott eredmények. A szervezetek között van már nagy múlttal rendelkező, évek óta jól működő cég, de található fiatal céget is, ami nem régen indult és éppen abban a fázisban van, amikor próbálja felvenni a versenyt a nagyobbakkal és ehhez próbálja megteremteni a megfelelő körülményeket.

A különbség természetesen látható a szervezetek informatikai struktúrájának felépítésében és működésében is. Cégek és szervezetek szint- jén már nem is annyira a biztosítás használata, sokkal inkább a különböző módozatok jelenléte az, ami számít. Természetesen alapvetően meghatározza a biztosításhoz történő viszonyulását az, hogy milyen gazdasági helyzetben és milyen vagyontárgyakkal rendelkezik. Ezen kívül meghatározó a szaktudás illetve az ezzel a területtel dolgozó alkalmazottak ismereteinek a szintje valamint a dolgozók gyakorlata is.

Egy társadalom biztosítási kultúrájának szintjét az fejezi ki leginkább, hogy a közösség menynyire együttműködő, előrelátó és gondoskodó tagjaival szemben. A magyar lakosság egyébként rendkivül segítőkész, ha bajba kerül valaki a környezetében, de ugyanakkor hasonlóan bizalmatlan is, ha elöre kell gondoskodnia és "befektetnie". A kiszámíthatóság, a biztonság és a biztosítás iránti bizalom pedig éppen itt, ezen a ponton kezdődik. A magyar biztosítási piacra sajnos igaz, hogy a dij kicsit magas és éppen ezért lenne szerintünk létjogosultsága a vizsgált újszerű innovatív Mezőgazdasági támogatási rendszereknek. A megkérdezettek többsége 6.ábra: Milyen gyakorisággal és módon szokott Ön a szolgáltatásokért fizetni

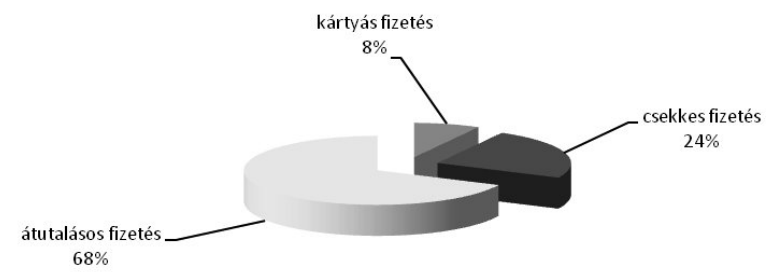

Forrás:Saját szerkesztés, 2013

(6.ábra) nem használ hitelkártyát vagy bankkártyát fizetéskor $8 \%$. Egyértelműek voltak a vélemények, általában a leggyakoribb fizetési mód az átutalásos eljárás $68 \%$ míg a csekkes fizetést választók száma eléri a $24 \%$-ot. Az átutalásos fizetéssel kapcsolatban kifejezetten bosszantónak ítélik, a különböző banki, ill. állami adókat - mint pl. a tranzakciós adót. 
A mélyinterjúkat a cégek nevük titkosítását kérték nyílván a bizalmas adatokra való tekintettel. Az interjúk elkészítésénél igyekeztünk mindig a saját környeztében nyugodt körülményeket biztosítani a tesz alanyok számára.

\section{BEFEJEZÉS}

A mélyinterjúk elemzésének célja, hogy a kérdésre adott összegzett válaszok és azok elemzése olyan input anyagot adjon, hogy meg tudjuk fejteni a miérteket azzal kapcsolatosan, hogy az újszerű mezőgazdasági támogatási rendszereket illetve a 2011.évi CLXVIII. tv és a 143/2011. (1223) VM rendelet adta lehetőségeket kihasználtsága az érintettek körében miért ilyen alacsony. A termelők saját felelősségteljes öngondoskodásának, a kármegelőzésre való törekvésüknek és az állam sok szabályozó, kármegelőző, támogató és együttműködő szerepének, a biztosítók bátrabb kockázatvállalásának lehetne hatékonyabb küldetése abban, hogy kiszámíthatóbbak legyenek mindazon befektetések, amely a magyar társadalom egy részétől és az adóbefizetők sokaságától származik. Reményeink szerint további tervek kiindulópontjaként is jól használható lesz a most kapott eredmény úgy, mint stratégiai alternativák illetve konkrét stratégiák kidolgozásához, valamint egyéb, a jelenlegivel összeegyeztethető, azzal kapcsolatban álló projektek generálásához.

Ezek megvalósításával terveink szerint még komplexebb módon tudjuk megvalósítani azon start-up lehetőségek kidolgozását, amik előre mutató megoldásokat és olyan figyelem felkeltő megjelenésre fog tudni alkalmat adni, aminek hatására miden érintett számára el jut az üzenet.

A mélyinterjú elemzésével kapott eredményről elmondható, hogy elég vegyes és sajnos többnyire negatív képet mutat a vizsgálat tárgyáról. A vizsgált régióban a legfejlettebb szférának talán a közigazgatási szféra mondható néhány területre vonatkozóan fenntartásokkal. A közigazgatási szervezetek más területeken jelentős állami támogatásban részesülnek ezen a téren viszont nem teljesen szabályozott a terület. Éppen ezért is javasoljuk, hogy a törvényhozás térjen ki e terület pontosabb konkrétabb szabályozásra és a képviseletük kerüljön bevonásra a törvényalkotásba. Ez nyilván érthető, hiszen elsődleges, hogy egységes és hatékony ügyintézés alakuljon ki ebben a szférában is. Az államnak is jobban megéri támogatni a fejlődést és korszerűsítést, mint az esetleges hiányosságokból adódó hibákat kijavítani. A második helyen a gazdálkodó szervezetek állnak. Ők is rendelkeznek mozgatható és elérhető forrásokkal, pályázati lehetőségekkel. Ebben a szférában jóval erősebb és kegyetlenebb feltételek uralkodnak. Sajnos a viszonylag lassú és bürokratikus fizetési feltételeknek még kevés cég veszi igénybe e támogatási lehetőségeket. Ördögi körnek nevezhető, amibe belekerülhetnek, főleg a kis- és középvállalkozók. Ezek vannak a régiókban, mint az ország egész területén is túlsúlyban. Saját maguknak kell megteremteni a versenyben maradáshoz szükséges feltételeket, ami azonban nehézségekbe ütközik, ha lehetőségük sincs bekerülni a versenybe. A magánszféra biztosítási helyzete abszolút jövedelemfüggő kérdés. Azok a családok, akik megengedhetik maguknak, azok könnyedén meg tudják kötni a biztosításokat. Akinek azonban nincs rá kerete, nagyon nagy hátránnyal indul. A legelmaradottabb családokon és személyeken mindenki érdeke lenne segíteni, hiszen az ő túlsúlyuk és felkészületlenségük teljes egészében hátráltatja társadalmi felzárkózásukat és nagyfokú társadalmi feszültséget szülhet, illetve szül is. Az alapprobléma mindhárom megkérdezett szféra esetében az új megoldásokra fordítható források hiányára, valamint néhány esetben a biztosítási és kockázatkezelési ismeretek hiányára vezethető vissza. Nincsen olyan forráslehetőség, amelyhez biztonsággal nyúlhatnának 
a megnevezett szférákon belül, ami pedig nagy lemaradáshoz vezethet, ha még időben nem orvosolják a problémát.

A különböző szférákhoz tartozó földterületeken szerződésen kívüli termelés nagy részben a hagyományokon alapuló várható kereslethez igazodik, amit a remélt értékesítési árak és a gazdaságok egyedi adottságai befolyásolnak. Az Alföld természet- és gazdaságföldrajzi jellemzői kedveznek a mezőgazdasági termelésnek, termőhelyi különbségei pedig területenkénti specializációt is lehetővé tesznek (pl. szabolcsi alma, szegedi füszerpaprika). „A terület mezőgazdasága így biztos alapot jelenthet a korábban már rátelepült élelmiszeriparnak, sőt, az Alföldön kívül levő feldolgozókhoz is kerül az itt megtermelt növényekből, vágóállatokból és állati termékekből." (4)

Az információhiánnyal kapcsolatban azt is meg kell említeni, hogy tulajdonképpen át kell nevelni az embereket, hogy megváltozzon az információs társadalomhoz való hozzáállásuk. Tudatosítani kell bennük, hogy alapvetően az ő érdekeiket szolgálja, ha egyszerübben és gyorsabban intézhetik ügyeiket, mint pl. az internet ehhez is segítséget jelenthet. Ehhez olyan oktatási programokat kell megvalósítani, ami nem igényel a részükről jelentős anyagi hozzájárulást. Ezeken az oktatásokon lehetőség van a környezettudatos, illetve termőhelyi adottságokhoz igazodó gazdálkodási módszerek elterjesztésére
- agrár-környezetvédelem - a meglévő, illetve új vidékfejlesztési támogatások folytatásáról és bevezetéséről szóló tájékoztatóknak is. „A kis vagy közepes családi gazdaságok intézmények - szaktanácsadói hálózat szükségessége - hiányában nem férnek hozzá a piacokhoz - közösségi marketing eszközei - a hitelekhez, támogatásokhoz, információkhoz." (5)

A világ mezőgazdasági piacainak kritikus helyzete sok agrár-országot arra a lépésre késztetett, hogy a mezőgazdasági termékek értékesítését rendszeresen támogassa. Így jöttek létre az alapvetően állami támogatású közösségi marketing szervezetek. „A biztosítókra - karöltve az állami támogatások rendszerével - a mezőgazdaságban is fontos szerep hárul. Gondoljunk csak azokra az állam által támogatott biztosítások kötésére, ahol az állam akár 2012-től 65\%-ban is támogatja a biztosítások kötését." (6) Másik fontos feladata a biztosítóknak az államilag támogatott gép-, illetve eszközvásárlások területén ezen értékek biztosítása olyan szinten és áron, hogy a mezőgazdasági cégeknek is megfizethetők legyenek

Ilyen és ehhez hasonló programok és projektek megvalósításának alapjául szolgál az elvégzett kutatás. Reményeink szerint hozzájárulhatunk ezzel az általunk vizsgált régió biztosítási és környezetvédelmi témában járatosabb társadalmának kialakulásához és fejlődéséhez.

Felhasznált irrodalom

[1.] http://www.biztositas.ma/mezogazdasagi_novenybiztositas_2012

[2.] http://tudastar.elelmiszerklub.hu/2012/11/ksh-magyar-mezogazdasag-helyzete-az-eu.html

[3.] http://www.ksh.hu/docs/hun/xstadat/xstadat_eves/i_omf003.html

[4.] http://www.ksh.hu/docs/hun/xstadat/xstadat_eves/i_qsma006.html

[5.] Szakács A. (2003): Termékfelelősség és biztosítása, doktori értekezés

[6.] Szakács A., Szakács Zs., Szabó A. (2012): A mezőgazdasági gépvásárlás valamint üzemeltetés a megújuló energiaforrások és a felelősség biztositások tükrében. XIII. Nemzetközi Tudományos Napok „Z̈̈ld gazdaság és versenyképesség?” című kiadvány, Gyöngyös, ISBN 978-963-9941-53-3, 1318-1324.p. 